\title{
IMPROVING ENGLISH SPEAKING ABILITY THROUGH HYPNOCATIVE SPEECH METHOD
}

\author{
Ninin Herlina \\ Universitas Trilogi Jakarta, Indonesia \\ E-mail: nininherlina@ trilogi.ac.id
}

\begin{abstract}
APA Citation: Herlina, N. (2018). Improving English speaking ability through hypnocative speech method. English Review: Journal of English Education, 7(1), 177-184. doi: 10.25134/erjee.v7i1.1567.
\end{abstract}

Received: 24-08-2018

Accepted: 26-10-2018

Published: 01-12-2018

\begin{abstract}
The objective of this research is to identify the improvement of students' English speaking ability through hypnocative speech. The research was conducted at Mantika Language Center. This action research was carried out in two cycles in which each cycle consists of four phases of planning, action, observation, and reflection. Here, the researcher guided the instructor as students' collaborators in implementing hypnocative speech method to improve students' English speaking ability. The data collection techniques used were observation, questionnaire, test, teacher's diary, observer's daily journal, interviews, and audiotape recordings. The data consist of collected accent, grammar, fluency, vocabulary and comprehension. The data have been collected through a critical comparative analysis technique by combining and simultaneously comparing the result of the first cycle until the last cycle. As result, it was found that implementing hypnocative speech in the teaching and learning process can improve students'attitudes and the outcome of their speaking ability. Here, the students can communicate fluently, do not feel afraid, and have more courage to speak the language communicatively, harmoniously, and correctly. Precisely, the implementation of hypnocative speech method can increase students' speaking ability, at least 30.31 .
\end{abstract}

Keywords: action research; speaking ability; hypnocative speech.

\section{INTRODUCTION}

In an effort to improve the quality and purpose of learning as one of the foreign languages in Indonesia, English gets an increasingly interesting space and interest by a number of participants of education. It is evidenced by the development of English training institutions with various methods that are created in supporting the teaching and learning process. The method was created with aims to overcome various challenges faced by students in learning English.

The challenge faced by students is related to the lack of methods that train students to improve their ability to speak English. English is not yet a daily language and is still regarded as a foreign language in Indonesia that is difficult to practice in everyday conversation. There is a lot of recognition of learners that they are not brave enough to speak English, they need maximum stimulation in order to succeed out words or speak English. Unreasonable fear has always been the subject of discourse in the low level of the ability to speak English. Fear is something natural and everyone has it. Yet, reconciling these fears and believing that fear is a learning process will lead to new awareness that can motivate students to be braver, comfortable, and especially enjoy the process. This condition really shapes the students to relax and become more motivated in learning.

Speaking is an activity of delivering an information and it is done by speaker to produce a mutually understood information between speaker and speech partner (Harmer, 2000). Basically, speaking has three purposes, among others, those are to inform something, toentertain, and to attract sympathy. Speaking is also defined as the ability to bring the discourse interactively in accordance with the objectives expected by the speaker or who is invited to speak (Brown, 2007). Moreover, Djiwandono (2008) adds the ability to speak is the ability to express one's thoughts and content through the sounds of language and 


\section{Ninin Herlina}

Improving English speaking ability through hypnocative speech method

words composed in complete language arrangements, such as phrases, sentences, and longer verbal discourses such as stories, speeches, etc.

Speech ability can be enhanced with Hypnocative Speech method. Hypnocative speech stands for hypnosis technology for mastering communicative speech. Hypnosis itself comes from the word hypnos which means sleep, but hypnosis itself is not sleep (Wong \& Hakim, 2009). Hypnocative speech is found based on the experience in producing

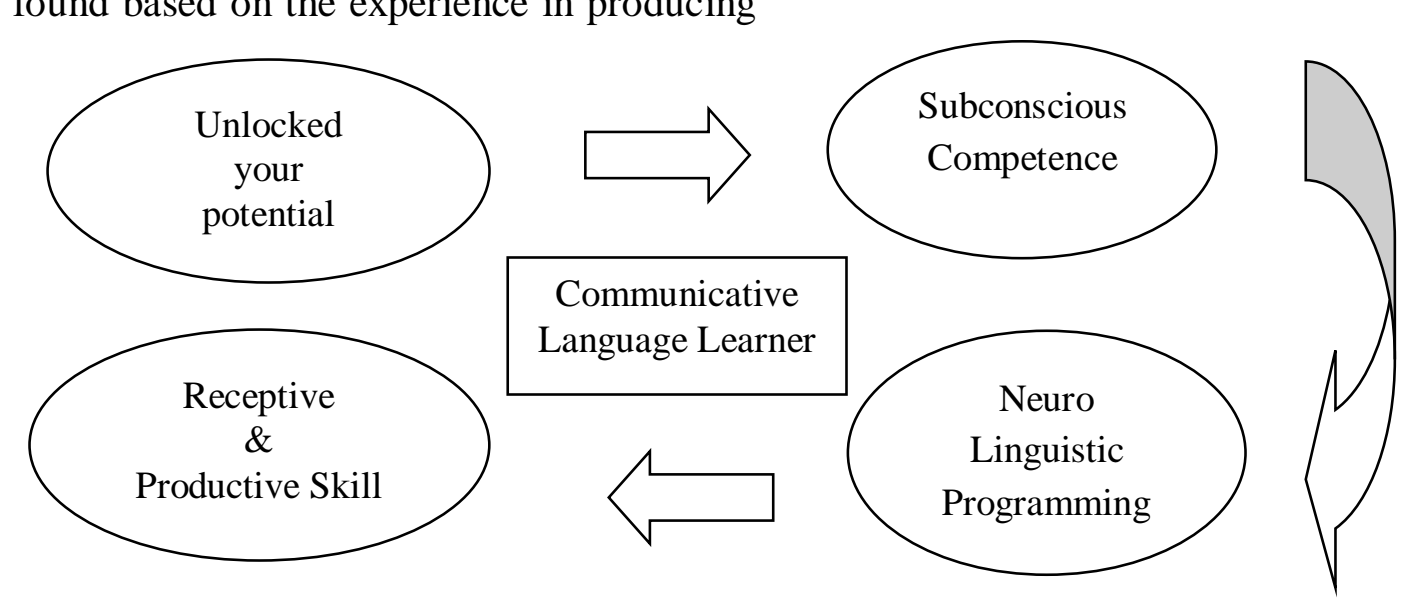

Figure 1. Hypnocative speech procedure (Hidayat, 2013) speech through hypnosis style. Hypnocative speech is English communication training by using Hypnosis and NLP (Neuro Linguistic Programming) technology (Hidayat, 2013). Hypnosis provides enjoy condition in relaxing the feel and mind. Hypnosis is a state of focused concentration and natural relaxation, that is how to relax and override the conscious mind (conscious mind, the will) as well as move the subconscious mind (subconcious mind) (Goldberg, 2007).
In the level of 'unlocked your potential', a teacher must formulate what positive things are the key to strengthening students to learn English. Besides, it also explores various obstacles found when learning English. In subconscious competence, the subconscious will produce more things that are put into the mind. So, suggesting positive, uplifting things for self-development is better. Neuro Linguistics Programming was introduced by Bandler physicist and Professor of Linguistics named Dr. John Grinder. Both combine the concept of language skills in the method of programming the nerves of each individual (Ghannoe, 2010). In the same book, NLP is defined as a science that studies the behavior of the human brain and how we use it, either to improve our thinking capacity or to communicate with others. The activity of human thinking is very important in determining the ability of a person to communicate because the balance of real brain work must be combined with the smooth motor in response. While in the process of neuro linguistics programming, students are very important to stimulate themselves into what they want to be.

Here, there will be anchor stage and modeling. Anchoring language can be interpreted as anchoring, tethering, or approach. Yet, in the context of this NLP, the anchoring here is only a metaphor of the language used in NLP to refer to one of the methods in NLP. In NLP, anchoring is one method of communication that uses a certain way so that the other person "does not go anywhere", stay focused and pegged to the origin or the base of the conversation. These ways can be words, sounds, smells, mood, view or gestures. This anchoring becomes the formula of each student in learning to manage their own potential in the best way or in accordance with the ability of students in learning.

In modeling, the student will determine how he needs to appear to master the situation. The circumstances give effect to the students to be able to master the material to be conveyed, for example when students learn English then he will try to find a suitable 
ENGLISH REVIEW: Journal of English Education Volume 6, Issue 2, June 2018

model, whether a presenter who fluent in English or a fluent lecturer give an explanation in English.

The next process embodied in the hypnocative sequence is receptive and productive skill. In this stage, someone is certain to have been able to practice and speak in English. Receptive that is all the steps that must be passed by students and continuously programmed subconscious mind to form a special ability, as in the stages of Neuro Linguistics Programming. Here, students are really trained and transposed to form the ability of self with full of spirit. Only then becomes easy in communication or productive skill formed.

Mantika is one of the institutions of English course that has been using hypnocative speech method as an effort to improve students' ability in learning English. In the preliminary observations conducted in Mantika as a foreign language training institute, the state of adults who have gained knowledge in formal educational institutions do not have enough ability to speak English in the real world or just make English as a communication tool with friends. Hypnocative speech method is used since it can explore the neurological factors which can balance the study with the management of motivation. Therefore, this research tries to identify the effectiveness of using hypnocative speech method to improve students' English speaking ability.

\section{METHOD}

The approaches used in this research were both quantitative and qualitative approach. This research used Kemmis and McTaggart model to conduct action research on improving English speaking ability through hypnocative speech method. This action research was carried out in two cycles in which each cycle consists of four phases of planning, action, observation, and reflection. This research involved students of employees' class in MANTIKA with a total of 15 students consisting of 6 female students and 11 male students. The study was conducted during the course schedule, i.e., Tuesday night and Friday night. Then, the data collection techniques
p-ISSN 2301-7554, e-ISSN 2541-3643

https://journal.uniku.ac.id/index.php/ERJEE

used are: observation, questionnaire, test, teacher's diary, observer's daily journal, interviews, and audiotape recordings.

Moreover, the criteria of success in this study is if $80 \%$ of the subjects were able to speak English with a total score of at least 70 or adjusted to the guidelines of the institution of the course and the average number determined is 15 points for the minimum score, while for the maximum average score is equal to 20 points, this is adjusted with the determination of success criteria in MANTIKA.

\section{RESULTS AND DISCUSSION}

The pre-test score was obtained from the test given at the beginning of the meeting to the students. In this pre test, the highest score was 15 and the lowest was 10 . The results indicated that the students' English speaking ability was still far from the standard of success criteria determined by the researcher based on the Mantika institute assessment guide.

\section{Cycle I}

The first cycle was done with a total of four meetings. Each meeting lasts for 120 minutes consisting of teaching and learning activities, student portfolio (self evaluation, self reflection and impression of teaching and learning process), analysis and reflection. At the end of the first cycle, the instructor described the procedure in hypnocative speech method. As a follow up step, instructors and collaborators inventoried and responded to suggestions provided by students. The suggestions given by the students were used as the basis for planning in the second cycle. Improved capabilities were kept in line with the signs which include accents, grammar, fluency, vocabulary, comprehension.

The first meeting is a continuation of the research process after the researchers made observations. At this meeting, the collaborators and instructors discussed about the lesson plan. Collaborators and Instructors agreed to enter the classroom together during the learning process. Instructors entered the class on time at 07.00 p.m.

At this meeting, the instructor opened the meeting with a motivational greeting and 


\section{Ninin Herlina}

Improving English speaking ability through hypnocative speech method

buzzing passionate phrases in English. Instructors encouraged students by introducing hypnocative methods as a suitable method for improving English language skills. The instructor explained that speaking is an important ability in learning English. This meeting is a preliminary meeting in teaching and learning that lasts for approximately 120 minutes.

At this inaugural meeting, the instructor delivered the material on 'Personal Mastery (Introduction)'. The instructor asked students to mention the desired target scale from 1 to 10 , the purpose of life, used for what, etc. The instructor also explained what is expected to achieve from each level of the elementary until the advanced level (target scale per level).

In this session, the instructor performed a placement test to determine the level of ability of each student. Students are able to measure their current ability and what will be achieved afterwards. This placement test is conducted by distributing paper questions to all students and students directed to solve a numbered problem.

The instructor noted the basic assumption of constraints that are often experienced by English learners. Two things to sort out are the constraints of software and hardware. Constraints software of English learners consists of shy, unconfident, afraid of making mistake, uncomfortable, able to understand but can not express, etc. In contrast, the constraints of hardware consist of tenses, vocabulary, listening, speaking, reading, and writing. These basic constraints must be solved by using hypnocative speech method in learning English.

Instructors described how the human brain is very sophisticated (amazing human brain). This knowledge is known as super memory, which explains the theory of brain intelligence and introduces the concept of NLP Anchoring over symbols such as yellow flags, red lights, mathematics, and so forth. This explanation is very important to dissect the sophistication of the human brain and give hypnosis to every student that all human beings have great potential to improve English proficiency.
After delivering the material at length, students were asked to respond to the basic spirit of learning English. Students were required to mention the purpose of learning English by using English as best as they can. Each student must also mention the perceived obstacles in each of them as well as mention firmly and loudly the expected target after following the learning by using hypnocative speech method.

The instructor listened carefully to what each participant was delivering while giving input or assisting students in expressing ideas in English. After all the students expressed their ideas one by one, the instructor gave feedback and reassurance that the students need not have any doubts or concerns in expressing their ideas because learning the language must be courageous to speak. Just speak and practice. The last 15 minutes were used to do relaxation. Each student took a special chair and lay down on the chair. The instructor rotated the relaxation music and turned off the lights so as to create a quiet class condition. The instructor started his hypnosis sentence by constantly speaking and directing the subconscious of the students to relax, calmly and instill in their minds that they can speak English fluently. They have tried to speak English well and correctly.

The fourth meeting was the same as the previous meeting, lasting for 120 minutes. However, at this meeting, instructors and collaborators tested the capabilities achieved from the first meeting to the third meeting referred to as the first cycle. This is important as it is a benchmark to know the smoothness, accuracy, vocabulary, and mastery in speaking. Besides, it was also done to find out how far the progress of students during the teaching-learning process and the extent to which students master the material that has been taught and learned during cycle 1 . The results of the assessment were combined between the assessment of the instructor's collaborative assessment. The results of the assessment are depicted in Table 1.

At the end of the first cycle, the instructor described the procedure in hypnocative speech method. Instructors have much to say about the substance that is expected of the hypnosis 
ENGLISH REVIEW: Journal of English Education Volume 6, Issue 2, June 2018

process to improve students' speaking ability and train them to be truly confident. Students also always ask for stimulus and guidance to
p-ISSN 2301-7554, e-ISSN 2541-3643

https://journal.uniku.ac.id/index.php/ERJEE

the instructor to develop more sentences in English and increase their vocabulary in every meeting.

Table 1. Test results of speech capability in Cycle I

\begin{tabular}{llllllll}
\hline No. & Name of Objects & \multicolumn{5}{c}{ Aspects of Assessment } & \multirow{2}{*}{ Total } \\
\cline { 2 - 6 } & & $\mathbf{A}$ & $\mathbf{G}$ & $\mathbf{V}$ & $\mathbf{F}$ & $\mathbf{C}$ & \\
\hline $\mathbf{1 .}$ & Object X1 & 3 & 2 & 4 & 3 & 3 & 15 \\
$\mathbf{2 .}$ & Object X2 & 3 & 2 & 3 & 2 & 2 & 12 \\
$\mathbf{3 .}$ & Object X3 & 3 & 3 & 4 & 2 & 4 & 16 \\
$\mathbf{4 .}$ & Object X4 & 3 & 4 & 4 & 2 & 3 & 16 \\
$\mathbf{5 .}$ & Object X5 & 4 & 3 & 4 & 4 & 3 & 18 \\
$\mathbf{6 .}$ & Object X6 & 3 & 3 & 4 & 3 & 3 & 16 \\
$\mathbf{7 .}$ & Object X7 & 3 & 3 & 4 & 3 & 3 & 16 \\
$\mathbf{8 .}$ & Object X8 & 3 & 3 & 4 & 2 & 3 & 15 \\
$\mathbf{9 .}$ & Object X9 & 3 & 2 & 4 & 3 & 3 & 15 \\
$\mathbf{1 0 .}$ & Object X10 & 3 & 3 & 3 & 3 & 3 & 15 \\
$\mathbf{1 1 .}$ & Object X11 & 3 & 3 & 3 & 2 & 3 & 15 \\
$\mathbf{1 2}$ & Object X12 & 4 & 3 & 4 & 2 & 3 & 16 \\
$\mathbf{1 3 .}$ & Object X13 & 4 & 3 & 4 & 3 & 3 & 17 \\
$\mathbf{1 4}$ & Object X14 & 3 & 4 & 4 & 3 & 4 & 18 \\
$\mathbf{1 5 .}$ & Object X15 & 4 & 3 & 4 & 3 & 3 & 17 \\
& Total & & & & & & $\mathbf{2 3 6}$ \\
& Average & & & & & $\mathbf{1 5 . 7 3}$ \\
\hline
\end{tabular}

The result of speech test in cycle I showed that the highest score was 18 points and the lowest score was 15 points. From the results of the test cycle I, it was seen that there were five students whose value reaches a minimum standard. There were 10 students whose value has reached above standard. In this cycle, there has been an improvement in students' English speaking ability. However, researchers continued to take action in the second cycle as an effort to strengthen the ability to speak English.

Based on the quantitative analysis using ttest for non independent samples at the end of cycle-1, it was obtained t-test 7.27. The t-table value at the level $\alpha 0.05$ with $n=15$ was 1.75 . Thus, since the value of t-test was greater than t-table, then the test result was stated very significant. It can be concluded that there was a difference or an increase between the initial test result and the final test result of cycle I on English language proficiency test in Mantika Language Center.

Based on the results of reflection in the first cycle, a class action plan was planned for the second cycle. In this action plan, the instructor prepared the Lesson Plans that were used to carry out the learning in accordance with the steps that had been set.

\section{Cycle II}

Based on the results of the reflection on the first cycle, a class action plan was planned for the second cycle. In this action plan, the Instructor prepared the Lesson Plans that were used to carry out the learning in accordance with the steps that have been set. Implementation of action in this second cycle is a continuation of the first cycle. Learning in the first cycle was not yet reached the set standard. Thus, it is considered necessary to continue to the next cycle. Learning in the second cycle was held in three meetings and one meeting to conduct test.

Implementation of action in Cycle II is a re-training of cycle I with different materials and held in two meetings a week. The learning materials were about super memory, the introduction of Quick Tenses Mastery, Quick Tenses mastery Simple Past, Quick Tenses mastery Simple present, Quick Tenses mastery Simple future, and Practicing Quick Tenses mastery.

At the end of the second cycle, students had been able to conceptualize and up date information with good sentences. Students asked for many stimuli that can develop their speaking skills. The instructor was able to manage the class well. 


\section{Ninin Herlina}

Improving English speaking ability through hypnocative speech method

As a follow-up step, instructors and collaborators inventoried and responded to suggestions provided by the students. The enhanced capabilities were kept in line with the signs mentioned earlier, which include accents, grammar, fluency, vocabulary, comprehension. The researchers and collaborators then perform data tabulation as an overview of the student's ability to speak during the second cycle.

Table 2. Test results of speech capability in Cycle 2

\begin{tabular}{clccccccc}
\hline No. & Name of Objects & \multicolumn{6}{c}{ Aspects of Assessment } & \multirow{2}{*}{ Total } \\
\cline { 3 - 6 } & & $\mathbf{A}$ & $\mathbf{G}$ & $\mathbf{V}$ & $\mathbf{F}$ & $\mathbf{C}$ & \\
\hline $\mathbf{1 .}$ & Object X1 & 3 & 4 & 4 & 4 & 3 & 18 \\
$\mathbf{2 .}$ & Object X2 & 3 & 4 & 4 & 4 & 3 & 18 \\
$\mathbf{3 .}$ & Object X3 & 3 & 4 & 5 & 3 & 4 & 19 \\
$\mathbf{4 .}$ & Object X4 & 3 & 4 & 5 & 4 & 4 & 20 \\
$\mathbf{5 .}$ & Object X5 & 4 & 3 & 5 & 4 & 4 & 20 \\
$\mathbf{6 .}$ & Object X6 & 4 & 4 & 4 & 4 & 4 & 20 \\
$\mathbf{7 .}$ & Object X7 & 5 & 3 & 4 & 4 & 3 & 19 \\
$\mathbf{8 .}$ & Object X8 & 4 & 4 & 4 & 4 & 3 & 19 \\
$\mathbf{9 .}$ & Object X9 & 5 & 4 & 4 & 4 & 5 & 22 \\
$\mathbf{1 0 .}$ & Object X10 & 3 & 3 & 5 & 4 & 3 & 18 \\
$\mathbf{1 1 .}$ & Object X11 & 4 & 5 & 5 & 3 & 4 & 21 \\
$\mathbf{1 2 .}$ & Object X12 & 5 & 3 & 5 & 4 & 3 & 20 \\
$\mathbf{1 3}$ & Object X13 & 5 & 3 & 4 & 4 & 3 & 19 \\
$\mathbf{1 4}$ & Object X14 & 3 & 4 & 4 & 4 & 4 & 19 \\
$\mathbf{1 5 .}$ & Object X15 & 5 & 3 & 4 & 3 & 4 & 19 \\
& Total & & & & & & $\mathbf{2 9 1}$ \\
& Average & & & & & & & $\mathbf{1 9 . 4}$ \\
\hline
\end{tabular}

While the results of speech test in cycle II showed that the highest score was 22 points and the lowest score was 18 points. From the results of the test cycle II, it was seen that students had experienced improvement in the ability to speak with the acquisition of test scores reached maximum standards. Thus, it showed that the students' condition improved for the better.

Based on the quantitative analysis, it was obtained t-count 30.13 . The $t$-table value at the level $\alpha 0.05$ with $\mathrm{n}=15$ was 1.75 . Thus, since the value of t-test was greater than t-table, then the test result was stated very significant. It can be concluded that there was a difference or an increase between the initial test results with the final test result of cycle II on the English language proficiency test in Mantika Language Center.

In the second cycle, it was proved that the improvement of students' English speaking ability had increased along with the maximal level of action in combining the learning method by using hypnocative speech method. This step further answers the hypothesis that the application of Hypnocative Speech method increased the students' ability to speak English at Mantika Language Institute.

\section{CONCLUSION}

Implementation of learning by using hypnocative speech method in improving students' English speaking ability of Mantika Language Center Tebet run well and smoothly. Initially, it is still experiencing difficulties and has not run effectively. However, after running 4 meetings in cycle I and entering cycle II, the learning by using hypnocative speech method can run smoothly and interesting. The actions taken in each cycle are performed by students with enthusiasm and full motivation. Here, the students began to actively participate in the teaching and learning process. The students have already understood about the benefits of hypnocative speech method in learning.

The hypnocative speech method included several techniques that were integrated into it and it can improve students' English speaking ability. This was indicated by an increase in the number of students who had increased their ability to speak from Cycle I to Cycle II. The increase occurred in the students' speaking 
ENGLISH REVIEW: Journal of English Education Volume 6, Issue 2, June 2018

ability that was from 14.77 percent in the first cycle and reached 17.2 percent in the second cycle. Thus, there was a significant increase from cycle I to cycle II.

In the second cycle, it was proved that the improvement of students' English speaking ability had increased along with the maximal level of action in combining the learning method by using hypnocative speech method. This step further answers the hypothesis that the application of Hypnocative Speech method increased the students' ability to speak English at Mantika Language Institute.

\section{REFERENCES}

Brown, D. (2007). Language assessment: Principles and classroom practice. White Plains, NY:Pearson Education.
p-ISSN 2301-7554, e-ISSN 2541-3643 https://journal.uniku.ac.id/index.php/ERJEE

Bygate, M. (2001). Researching pedagogic tasks: Second language learning, teaching, and testing. UK: Longman.

Harmer, J. (2001). The practice of language teaching. White Plains, NY: Pearson Education.

Harmer, J. (2000). How to teach English. London: Longman.

Heaton, J. B. (1989). Writing English language test. London: Longman.

Kember, D. (2000). Action learning and action research: Improving the quality of teaching and learning. London: Biddles ltd.

Nunan, D. (1992). Research methods in language learning. Cambridge: Cambridge University Press.

Sugandi, A. (2004). Teori pembelajaran. Semarang: UPT MKK UNNES.

Tarigan, H. G. (1985). Berbicara sebagai suatu keterampilan berbahasa. Bandung: Angkasa.

Valette, R. M. (1967). Modern language testing. New York: Harcourt Brace Javanovich. 


\section{Ninin Herlina}

Improving English speaking ability through hypnocative speech method 